breaking up of drops ${ }^{6}$ and/or a turbulence effect ${ }^{2}$ may have been operative, neither of which is provided for in Bowen's theory.

It is hoped to conduct further experiments this year using similar techniques. In these experiments it is proposed that the particle size of the hygroscopic substance shall be reduced to about $20 \mu$ diameter, with the object of producing water drops in the cloud initially of about $50 \mu$ diameter. The particle size hitherto used has been mainly between $50 \mu$ and $75 \mu$, which results in water drops at least $100 \mu$ diameter. This revised procedure should result in more rain being produced, but after a longer time interval.

1 Davies, D. A., Nature, 167, 614 (1951).

${ }^{2}$ Davies, D. A., Nature, 169, 1001 (1952).

${ }^{3}$ Davies, D. A., I Hepburn, D., and Sansom, H. W., E.A. Met. Dept. Memoir, 2, No. 9 (1951). 4 Davies, D. A., Hepburn, D., and Sansom, H. W., E.A. Met. Dept.
Memoir, 2, No. 10 (1952).

- Bowen, E. G., Quart. J. Roy. Met. Soc., 78, 37 (1952).

6 Ludlam, F. H., Quart. J. Roy. Met. Soc., "y', 402 (1951).

${ }^{7}$ East, T, W. R., and Marshall, J. S., Quart. J. Roy. Met. Soc., 80, 26 (1954).

\section{DUTCH-NORWEGIAN JOINT ESTABLISHMENT FOR NUCLEAR ENERGY RESEARCH}

\section{REPORT FOR THE YEAR 1952-53}

T

HE Joint Establishmont for Nuclear Energy Research (JENER), which was set up in April 1951 jointly by the Netherlands and Norway for the purpose of carrying out research and development work in the field of atomic energy, is supported financially by the governments of the two countries and by private industry. The Establishment is governed by a joint commission consisting of three representatives from the Netherlands and three from Norway and is directed by Mr. Gunnar Randars. The organization's research establishment and laboratories are situated at Kjeller, fifteen miles north-east of Oslo, Norway, and include the heavy-watermoderated uranium reactor, Joint Establishment Experimental Pile (JEEP), which is now in continuous operation. The second annual report of the Estab. lishment, which has now been published*, gives full details of the progress made during 1952-53.

The factual report is preceded by the text of the opening address which Mr. Randars delivered at the international conference on heavy-water reactors held at Kjeller and Oslo during August 11-13, 1953, and by a short descriptive article on recent developments in radioisotope production and application in Norway. In his address, Mr. Randars explained that the main purpose of the conference was to hear the opinions of scientific workers as to the possibilities and difficulties of the particular approach adopted by Norway to the study of atomic energy, namely, by working exclus. ively with heavy-water reactors and natural uranium. It is not known whether reactors with natural uranium are practical for use in industry; but Mr. Randars asserted that, so far during the work at the Establishment, nothing has been found to rule out the possibility. The cost of fuel in a natural uranium reactor is approximately the same as in an enriched reactor; but the extremely high cost of heavy water presents

* Joint Establishment for Nuclear Energy Research. Second Annual Report, 1952/53. Pp. iv +41 . (Blindern, Oslo: Akademisk Trykningssentral, 1953.) a real problem for the future of heavy-water reactors. Mr. Randars outlined his reasons for the selection of a heterogeneous reactor-that is, one with uranium rods in heavy water-and pointed out that in such a reactor 1 per cent of the uranium could be burnt. He said that at Kjeller they are considering the construction of a heterogeneous heavy-water reactor to produce up to $25,000 \mathrm{~kW}$. This reactor would use 10 tons of uranium, be cooled by heavy water at a temperature slightly above $200^{\circ} \mathrm{C}$. and at a pressure of 35 atmospheres, and be moderated by heavy water at approximately $60^{\circ} \mathrm{C}$. Attached to the boiler there would be a saturated steam turbine of about 25 per cent efficiency. The insulating material between the hot circulating heavy water and the cooler moderator might be beryllium oxide. It was hoped that the money for the venture would be forthcoming, but in the meantime considerable progress is being made with the design of the reactor.

The annual report mentions that since September $1952 \mathrm{JEEP}$ has been in almost round-the-clock operation for five days a week-during ordinary staff working-hours for experimental work by the scientific staff, and at other times at maximum power-level for isotope production. In order to compensate for the heavy load of isotope material, two additional fuel rods, making a total of sixty-four, have beer inserted in the reactor. The shielding has also been improved, and a mechanical system for extracting fuel rods has been constructed in addition to a storage cell for hot rods. Methods of visual inspection of the rods and of the inside of the reactor have been developed, and a permanent unit for recombination of dissociated heavy water built and installed. The extraction of heat from the reactor takes place in two stages, first from the heavy water to ordinary water and then from the ordinary water to free air. The hot air was originally discharged into the atmosphere, but now the heat from the air has been harnessed and utilized to heat the reactor hall. The extension to the reactor building to house new laboratories and offices was due for completion in September last.

Steady progress has been maintained with the equipping of the chemical laboratory, and an adequate staff has now been built up. The spectrographic laboratory is fully equipped, and some metallurgical research has been commenced. The constant surveillance of the heavy water in the reactor and some preliminary research work in transuranium chemistry are two of the main activities of the Chemistry Department which are specifically referred to in the annual report.

Work in the Physics Department has been directed more and more towards pile neutron physics, and the Kjeller reactor has proved to be a useful tool for physics research. The equipment and facilities available for neutron spectroscopy and neutron diffraction are described and illustrated in the report, in addition to the pile oscillator, gamma spectrograph, pulse height analyser, beta spectrometer and mass spectrometers. For the routine production of radioisotopes, resulting in a hundred and forty isotope shipments and service irradiations for customers outside the Establishment, and ninety-seven for the use of the Establishment's own staff, the reactor has been operated at an energy-level giving 1-5 $\times 10^{11}$ neutrons $/ \mathrm{cm}^{2} / \mathrm{sec}$. thermal neutron flux in the isotope channels and about eighty hours of effective irradiation time per week. Deliveries of carrier-free iodine131 commenced in February 1953, and radioactive 
gold was expected to be ready for production by the end of the year. The preparation of organic compounds labelled with carbon-14 has boen continued, and some fifteen compounds are now availakle. In the autumn of 1952 a regular consultative service was started by the Isotope Department for Norwegian industry, and details of the various industrial firms and the investigations undertaken with the particular isotopes used are listed in the annual report.

The final sections of the report deal briefly with reactor development; health physies; the informa. tion service and its publications ; the accounts of the Establishment for the period July 1, 1952-June 30, 1953 ; the personnel in the various departments; and the various scientific mcetings and conferences attended by members of the staff of the Establishment during the period under review.

\section{BRITISH HYDROMECHANICS RESEARCH ASSOCIATION}

\section{ANNUAL REPORT FOR 1952-53}

$\mathrm{T}$

HE sixth annual report of the British Hydromechanics Research Association, covering the period October 1952-September 1953*, records satisfactory development in both the activities and finances of the Association. Although the scale of operation is modest, it is stated that the Association's technical prestige has risen considerably and that it is being consulted as an authority on fluid mechanies by a widening range of industries.

The first five-year period of government grant-aid expired at the end of the year under review, and an application for its continuation and augmentation submitted to the Industrial Grants Committee was roceived sympathetically. However, the new grant, although rising to a higher maximum than the original, is not so favourably proportioned; for the first $£ 18,000$ of income the grant is $£ 9,000$ and then $£ 75$ per $£ 100$ up to a maximum additional grant of $£ 9,000$. It is expected that subscriptions from present members for 1953-54 will exceed the minimum grant-earning figure.

The two visitors to the Association, Brigadier R. A. Bagnold and Prof. L. Rosenhead, appointed by the Department of Scientific and Industrial Research, continued to take a keen interest in the activities of the Association and to attend meetings of the Council and research committees. During the year the constitution of these committees was revised, and those formerly dealing with fundamental fluid mechanics, instruments, and pipe-flow problems were combined into a single committee dealing with non-machinery problems, while the other research committees were enlarged. Details of these committees, together with a list of their members, and of the ordinary and associate members of the Association, are given in the report.

The staff of the Association has been increased and now numbers thirty-three, the senior staff consisting of the diroctor of research, Mr. L. E. Prosser ; the deputy director of research, Mr. R. C. Worster; five research engineers and one junior research engineer; the secretary and the librarian. From the

* British Hydromechanics Research Association. Sixth Annual Report, October 1952 to September 1953. Pp. 26. (From the Association, Nettleswell Road, Harlow, Essex.) research work undertaken since the Association's laboratory was opened in 1951, much useful information has emerged, particularly in relation to sump design, pulsating flow metering, pre-rotation in centrifugal pumps and the precision manometer. Some of the more recent work and of the results obtained are briefly described in the annual report. Instruments for the metering of pulsating flows have been successfully developed, and preliminary work with simple suction-pump layouts has been extended to models of actual or proposed installations. The collection and study of data on the friction loss in pipes and fittings have now been completed. A technical note dealing with the pressure surges resulting from a failure of the power supply to a pumping set has recently been published and, as little information is available on the subject, work has been started on an investigation of the rate of gas release from liquids when the pressure is reduced.

There is considerable interest in the hydraulic transport of large coal, and the Association has accordingly undertaken an extensive investigation of the basic hydraulic process involved. The results obtained so far indicate that the hydraulic transport of coal on a large scale should be economic over distances of several miles. A promising application is the vertical transport of coal from the pit bottom or working face to the surface, and the main practical problem of raising the mixture of coal and water to the required pressure is being tackled by the development of a coal feeder for delivering the coal into a pipeline where the water has previously been raised to high pressure by conventional means.

Fuller information about the various investigations can be obtained from the numerous technical notes, research reports and published papers of the research staff of the Association, a complete list of which is included in the annual report.

\section{INSTITUTE OF PHYSICS \\ ANNUAL REPORT FOR 1953}

$\mathrm{T}$ HE thirty-fourth annual report of the Board of the Institute of Physies, covering the work of the Institute during 1953 (obtainable from the Institute at 47 Belgrave Square, London, S.W.1), records that the Board of the Institute met six times, and its various standing committees twenty-four times, during the year. The membership increased by 248 to 4,595 . Applications for election or transfer to the various grades of membership of the Institute received during 1953 numbered 581, compared with 651 in the previous year. The degrees of a further four universities, in particular the newly established degree in applied physies of the University of Manchester and the associateship in applied physics of the Royal Technical College, Glasgow, were recognized by the Board, and two technical colleges which had applied for extension of recognition were visited by representatives of the membership and examinations committee. Seven of the thirty-two candidates for the graduateship grade of membership of the Institute were successful; for the National Certificates in applied physics the numbers of candidates continued to increase, being 151 candidates for tho ordinary level and 55 for the higher cortificate, compared with 137 and 33, respectively, in 1952. 